\title{
THE SHAPE OF THE NEW: FOUR BIG IDEAS AND HOW THEY MADE THE MODERN WORLD, BY SCOTT L. MONTGOMERY AND DANIEL CHIROT (OXFORD, PRINCETON UNIVERSITY PRESS, 2015)
}

\author{
Juhi Pandyal
}

In this book, the authors talk about the ideas that have been of immense importance as the sources of decisions and actions that constructed the modern world - those ideas that have been and remain amongst the most central to the modern understanding of the nature and workings of human society. It was in the late seventeenth, eighteenth and early nineteenth centuries when most of the ideas fundamental to modernity were born. The authors claim that contemporary society has been built over time from the materials of thought, and support the notion that ideas have been among the primary forces behind modern history during the past three centuries. All the different ideas that are discussed in the book - concerning the Enlightenment, politics, economics, social science and religion - have been put to many different uses since they first appeared, and show no signs of going away. One of the foremost goals of the authors in claiming the power of these ideas as primary historical forces is to identify their implications for the scholarship and teaching of both social sciences and the humanities. Each chapter takes a key domain of idea-making and traces its origins, logic, and relevance to the ongoing debate.

The book is divided into two parts. The first part ('Inventors of Modernity') describes the theories of Adam Smith, Karl Marx, and Charles Darwin, as well as debates between Thomas Jefferson and Alexander Hamilton. The second part ('Secular and Religious Reactions against Enlightenment') deals with ideas that have arisen to confront the Enlightenment. This includes writings about Christianity and Islamic modernism, both of which surged in influence in many parts of the globe during the late twentieth and early twenty-first century. The writings referred in the book portray the Enlightenment perspective on the

1 Juhi Pandya is a Ph.D. student at the Doctoral School of Sociology, Corvinus University of Budapest; e-mail: juhipandya285@gmail.com 
domain of ideas under discussion, particularly in relation to the Middle East, Europe, and the United States.

The introductory chapter presents the authors explanation for choosing the ideas they include, and explains the influence of these on the lives of people in the modern world. The authors think that the twentieth century world was built in substantial part on the ideas of Adam Smith, Karl Marx, and Charles Darwin, but it was also the attention they attracted due to their enlightened vision of progress that was championed. Book chapters follow a specific framework: they start by providing detailed information, including a brief description of a scholar's personal life from birth to death, including family details and educational and career achievements. They also describe how the scholars started their research and produced the eminent work which inspired the world. Prominent relations with other scholars are mentioned within each chapter to clarify how such scholars were linked to each other during their lives. These readings hint that the surrounding environment plays a supportive role in nurturing ideas. The authors' aim is to synthesize what is known about these scholars and concepts into a coherent set of discussions about their diverse, long-term impact.

The chapter on Adam Smith, a humanist intellectual and moral philosopher who ventured into economics, briefly mentions his work 'The Theory of Moral Sentiments' and his book 'The Wealth of Nations'. The authors argue that Adam Smith's central concern was freedom, something that was revolutionary then, and remains vital today. The authors opine that Adam Smith favored two different groups of believers in the inherent value of capitalism as a progressive, efficient, and liberating way of organizing modern societies. On the one hand, he offers clear support for making the free market the single most important method of creating and spreading wealth. On the other hand, he includes those who agree with these goals, but who also consider the role of governments to be vitally important.

The chapter on Karl Marx includes information about dialectical materialism, methods of production, capitalism, and discontent. Authors describe how Marxism is connected to depression, war, Maoism, and revolution through the spread of communism in Europe and Asia. It was not communism itself, but the many forms of socialism, including that of the political parties of the late nineteenth century, which served as precursors to the emergence of the large socialist parties that existed around the world in the twentieth century. These were inspired by Marx, and were considered to follow his views. Powerful nations like the Soviet Union and Maoist China organized themselves around his theories. The pessimistic and affirmative effects of Marxism are discussed in this chapter of the book. In any case, where Marxism (mostly in the guise of Leninist and Maoist adaptions) did come to power, it produced economic 
systems that succeeded for a short time, and then failed catastrophically. Marx's outrage about capitalism is today mainly manifested in the forces of antiglobalization and the strong anti-liberal reactions that are shared by many. The related literature is broad, and supports understanding of the views that have developed in the past in relation to capitalism.

The chapter on Darwin enlists work from his book 'On the Origin of Species'. The book was influential around the world, claim the authors. The theories of Herschel and Paley, Lamarck and St. Hilaire were early influences on Darwin. No less important was Darwin's influence on Sigmund Freud. Literature about the consequences of eugenics and Darwinism in a European, MiddleEastern, and Eastern Asian context is referenced. Social Darwinism and its associated problems are also discussed in the chapter. Critical literature speaks of the rejection of Darwin's ideas, especially among Catholics and Evangelical Protestants, and to some extent the French.

The 'Making Democracy' chapter revolves around the role of the United States in institutionalizing and preserving Enlightenment liberalism. The debate is centered on the ideas of Jefferson and Hamilton about democracy in the United States. These thinkers both shared core ideas about what values the United States should most embody. The ideas represent two overlapping yet also conflicting dimensions of the enlightenment concept of freedom. Hamilton saw the need for strong central authority, a large military, a federally driven industrial economy and an active foreign policy, while Jefferson promoted a weak center, local militias, a nation of yeoman farmers and entangling alliances with nobody. Both understood liberty as an absolute good, and believed that freedom from oppression was an absolute requirement if man was to discover and develop his natural capabilities. Both men, therefore, saw power as the problem, and its control as the solution. The authors opine that the persistence of Enlightenment ideas in both forms has saved America many times from fullscale regression, and probably will again.

The second part of the book presents thoughts about the Counter-Enlightenment. Under this topic, the authors discuss the birth of modern reactionary politics and popular reactions against liberalism: the role of nationalism, the new antiSemitism and the growing European rejection of liberalism. They also discuss the intellectual roots of fascism and varieties of fascism from Europe to East Asia, the Middle East and Latin America (Argentina). The profound effect of the rejection of enlightenment values is discussed by authors. The authors suggest that Counter-Enlightenment ideologies need to be analyzed seriously and met with equally learned and persuasive arguments. Otherwise, they will poison a whole era, just as they did much of Europe in the first half of the twentieth century and other parts of the world. 
The following chapters address fundamentalist religions; namely, the largest and the most widespread in terms of the number of adherents - Christianity and Islam. Montgomery and Chirot discuss the background and context of Christian fundamentalism from post-classical times until the twenty-first century, and Evangelical Christianity and women's rights in terms of the United States, Canada, and Europe. Islamic modernism is also discussed. Enlightenment thinking has had a much harder time of it in the Muslim world. Some distinguished Muslim thinkers have tried to create a compromise between modern (even partly liberal) ideas and religious faith. The authors claim that there are economic and socio-political reasons for Salafism's rise and persistence. The Christian and Muslim rejection of modernity, particularly their denial of the core values of Enlightenment liberalism, are strikingly similar in a number of areas. The authors point out the fact that the establishment of these anti-Enlightenment ideas has made the world a far worse place, corrupted and enfeebled. Hence, the original ideas that support the anti-Enlightenment need to be refuted and replaced.

The book provides an overview of changes in the world that have occurred due to the most influential ideas that have emerged from the different domains of thinking that relate to human welfare. It is acknowledged that ideas have immense power to shape the world and society. The book represents a vast platform of knowledge due to the presence of its micro-level detail. This gives the reader a precise understanding of the occurrence of the ideas that are presented, as well as the opposition to them. Literature about Islamic and Christian modernism is a bonus. The authors believe that rejection is also a form of influence. One important component of the book is the description of incidents in the personal lives of the scholars that they reflect on, giving more power to the authors' ideas. However, the content is sometimes a little extended.

The authors thoroughly focus on the implications of their findings for scholarship and teaching in the social sciences and humanities. They posit that critical reading and discussion of the texts that have been immeasurably important in the creation of the modern world ought to be an essential part of higher education. They also state that the humanities are essential components of any system of higher education, because no program of learning that aims to engage and prepare students for the wider world, and for citizenship in that world, can do without the study, analysis and critical evaluation of ideas. 